\title{
UNCONTROLLED EXPANSION IN THE LIGHT AND POWER INDUSTRY
}

\section{RICHARD JOYCE SMITH $†$}

IT has been characteristic of public utility regulation in the United States to defer governmental interference with private management until abuses have become too flagrant to be ignored. Statutory control as established by II unn v. Illinois ${ }^{1}$ came only after reckless rate practices of railroads had goaded shippers of the middlewest into disorderly political agitation.2 Subsequent extensions of governmental authority have followed in the wake of newly discovered abuses. Improvident capitalization endangering the interests of consumers and investors has led to the supervision of security issues. ${ }^{3}$ Inadequate, if not misleading, corporate records have resulted in the prescription of uniform systems of accounting." And the recently disclosed malpractices of holding companies have at last demonstrated the necessity for restraints upon intercorporate affiliations."

One disadvantage of this theory of regulation is that the statutory amendments or changes in administrative routine required to control

$\rightarrow$ Associate Professor of Law, Yale University. See the author's The Judicial Interpretation of Public Utility Franchises (1930) 39 TALE L. J. 957.

1. 94 U. S. 113 (1877).

2. See Buck, The Agrarian Crusade (1920).

3. Webster Mranufacturing Company จ. Byrnes, 207 Cal. 630, 280 Pac. 101 (1929); Public Service Commission v. Consolidated Gas Co., 14S MId. 90, 129 Atl. 22 (1925); Public Service Commission v. State, 184 Ind. 273, 111 N. E. 10 (1916); Wisconsin Hydro-Electric Company v. Railroad Commission, 236 N. W. 663 (Wis. 1931).

4. State v. Atchison, Topeka and Santa Fe Railway Co., 115 Kan. 3, 221 Pac. 259 (1924); Moster and Cratword, Public Utmity Regulation (1933) c. 10.

5. Comment (1933) 42 YaLE L. J. 941; Note (1933) 46 Hanv. L. REv. 508; Lilienthal, Recent Developments in the Law of Public Utility Regulation (1931) 31 GoL. L. REv. 189. 
a new situation are seldom made as soon as the need arises. Even after an abuse in private management has been uncovered there is usually an interlude during which the challenged practice continues to have free play. But a more fundamental disadvantage is that the prevailing policy implies an abdication of government from any part in the initial development of public utility industries. Much attention has been devoted to the punitive side of utility regulation, but little provision has been made for the cooperation of public agencies and private managers in the interest of an orderly expansion from the outset of a particular industrial development.

This absence of governmental initiative may be of little significance where the industry involved has already reached a natural state of disintegration, as seems to be the case with street railronds. But it has serious consequences where the industry in question is undergoing rapid technological transformations or is entering upon a period of widespread territorial expansion. It requires no citation to point out that the irrational growth of railroad systems prompted entirely by the profit-making motives of competing entrepreneurs has been detrimental not only to the investors of capital and the shippers of goods but also to the country as a whole. Nor is it necessary to enter upon a detailed analysis to demonstrate that the revolutionary extensions of governmental control over the railroads contained in the Transportation Act of $1920^{\circ}$ and the drastic legislation now proposed ${ }^{7}$ to bring order out of chaos, are measures that come too late to prevent the harm caused by uncontrolled expansion. Whether any degree of public dictatorship will succeed in salvaging the railroads from the disasters that reckless private management has prepared for them remains to be determined by the outcome of the experiments upon which the national government is about to embark. Nevertheless the plight of that industry may serve as a warning to legislatures and administrative agencies in whose hands rests the authority to direct the development of other public utilities.

It is particularly timely in this connection to consider how far and along what lines governmental agencies should assume directive control over the expansion of the electric light and power industry. Technological developments in that field have already rendered the consolidation of small, individual plants economically desirable. On the other hand, competing groups of entrepreneurs have been alert

6. Texas and Pacific Ry. v. Gulf, Colorado and Santa Fe Ry., 270 U. S. 266 (1925) ; Texas and New Orleans Ry. v. Northside Belt Ry., 276 U. S. 475 (1928); Note (1926) 39 HARv. L. REv. 753.

7. See 8 U. S. Daily 135 (April 29-May 6, 1933). 
to recognize the possibilities of such consolidations and through far flung financial manipulations supplemented in part by actual interconnections have created a series of so-called systems which sweep indiscriminately across the country. ${ }^{8}$ The collapse of the Middle West Utilities Company ${ }^{9}$ together with numerous other examples ${ }^{10}$ of the detrimental effect of holding companies upon the efficiency and stability of operating units will be sufficient to insure adequate regulation of the financial phases of the industry. Here all that is required is the prevention of speculative manipulations and the extension of control over rates to include all transactions among the various constituents of intercorporate affiliations. If such control eliminates the pyramiding of profits and to that extent destroys the raison d'etre of holding company systems, the electric light and power industry as such need not suffer. There may be ultimate loss to investors, the responsibility for which must be borne alike by the private interests that promoted and the governments that failed to prevent the schemes, but a sound and rational development of the industry need not be impeded.

Danger to a proper development of the industry does lie, however, in the lack of governmental supervision over physical or territorial expansion of the numerous private systems operating in the field. While the holding company has been primarily a device for financial control, it has to some extent promoted physical interconnections. ${ }^{11}$ A large number of the projects licensed by the Federal Power Commission have been shown to be controlled by holding company systems, ${ }^{12}$ and the investigations of the Federal Trade Commission have already disclosed that intercorporate affiliations in the light and power industry have usually been attended by physical interconnections. The American Gas and Electric System has high tension transmission lines extending from northern Indiana through

8. Bonbright and ileans, The Holding Company (1932). See aleo special report of Federal Power Commission, Holding Company Control of Liccnsces of Federal Power Commission (1932), and transcript of the proceedings of the Federal Trade Commission under Sen. Res. 83, 70th Cong., 1st Sess. (1927).

9. Danielson, From Insull to Injury (1933) 151 ATL. Mo. 497.

10. Note 6, supra. See also Re Alabama Power Co., P. U. R. 1932E, 323 (Ala. P. S. C. 1932); Re New Hampshire Gas and Electric Co., P. U. R. 1931D, 225 (N. H. P. S. C. 1931) ; Re New York State Electric and Gas Corp., P. U. R. 1932E, 1 (N. Y. P. S. C. 1932); Re Green Mlountain Power Corp., P. U. R. 1932A, 130 (Vt. P. S. C. 1931) ; Re Arizona Edison Co., P. U. R. 1932A, 238 (Ariz. C. C. 1931).

11. Field, Holding Corporation Control as a Provisional Form of Consolidation (1932) 8 Jour. LAND AND PUB. UTI. EcoN. 87.

12. Federal Power Commission, Holding Company Control of Liccnsces (1932) ix-x. 
Ohio and West Virginia to sections in Tennessee and Virginia. ${ }^{13}$ Power systems supervised by the Electric Bond and Share Company have been established on comprehensive scales in nineteen different states. ${ }^{14}$ Other systems whose development has been attended by territorial as well as financial consolidation are the Georgia Power Company, ${ }^{15}$ the Alabama Power Company, ${ }^{16}$ the New England Power Association, ${ }^{17}$ the North American System, ${ }^{18}$ and the Middle West Utilities System.19 But territorial expansion in the light and power field has not been confined to the growth of particular holding company systems. The interconnection under private auspices of "all the important power resources in the northeastern section of the United States" has recently been announced.20 The network is described as the fruits of twelve years of negotiation and construction, and involves interconnections not only among five holding company groups but also among a large number of independent operating companies. ${ }^{21}$

Governmental agencies have thus far exercised little control over this widespread movement toward the consolidation and interconnection of power territories. In keeping with the prevailing policy to regulate only against abuses, control of the light and power industry, like that of other utilities, has been primarily devoted to the protection of consumers from excessive rates or inadequate service, ${ }^{22}$ and has been deemed to be the function for the most part of agencies of the state governments. ${ }^{23}$ Such agencies have in the

13. Federal Trade Commission, Letter to United States Senate on Utility Corporations, no. 22 , p. 635 et seq.

14. Ibid, nos. 23-24, p. 403 et seq. (See Map facing p. 418 . It is to bo noted that the Electric Bond and Share System is composed of a series of intermediato holding companies each operating in its own section of the country. The policy of the Electric Bond and Share system is to interconnect its local plants in each state (see p. 409)).

15. Ibid. no. 28.

16. Ibid. no. 30.

17. Ibid. nos. 31 and 32 .

18. Ibid. nos. 33 and 34 .

19. Ibid. no. 38. The Federal Trade Commission has also held hearings on the activities of smaller systems and is still making investigations under Son. Res. 83 and 126, 70th Cong., 1st Sess. (1927, 1928).

20. N. Y. Times, May 7, 1933, Financial Section, at 7. '

21. I $\bar{d}$. at 9 .

22. Graver v. Edison Electric Illuminating Co., 126 App. Div. 371, 110 N. Y. Supp. 603 (2d Dep't 1908); Andrews v. North River Light and Powor Co., 24 Misc. 671, 53 N. Y. Supp. 810 (Sup. Ct. 1898).

23. "The Public Service Commission was established for the purposo of regulating corporations who rendered service to the public for which thoy were entitled to charge, that they might be required to render adequato sorvico 
past exercised some incidental control over territorial expansion. At the outset there was a tendency to consider the industry merely as one for the distribution of lighting energy ${ }^{24}$ within the confines of local communities, and, indeed, it was thought that the major function of the industry would be to supplant gas as a method of street lighting. ${ }^{25}$ For that reason the earliest form of public control over physical extensions was by means of municipal ordinances or franchises. ${ }^{26}$ The purpose of the control thus authorized was variously expressed as the supervision of street wiring, 27 the maintenance of the streets in a safe condition ${ }^{28}$ or the general regulation of the highways. ${ }^{20}$ While municipalities purported through the exercise of this control over streets to regulate the number of enterprises within its limits to the end that there would be neither exclusive monopolies nor unrestrained competition, ${ }^{30}$ little consideration was given to the necessity for public direction in the expansion of the industry. It was assumed that each enterprise terminated with muncipal boundaries, and the chief concern in the granting of a franchise became control over rates. ${ }^{31}$

Although most of the regulatory authority of the state has now been transferred to a centralized agency of the legislature, the

for a reasonable compensation." Gity of New York v. Prendergast, 202 App. Div. 308, 313, 314, 195 N. Y. Supp. 815, 819 (1st Dep't 1922).

24. See Scranton Electric Light and Heat Company's Appeal, 122 Pa. 154, 15 Atl. 446 (1888).

25. Gas Co. v. City of Davenport, 124 Iowa 22, 98 N. W. 892 (1904).

26. Attorney General v. Walworth Light and Power Co., 157 Miass. 86, 31

N. E. 482 (1892); Edison Co. v. Hooper, 85 Md. 110, 36 Atl. 113 (1897).

27. Note 26, supra. See also, Norwalk Electric Light Co. v. Common Council, 71 Conn. 381, 42 Atl. 82 (1899).

28. Citizens Electric Light and Power Co. v. Sands, 95 Mich. 551, 55 N. W. 452 (1893).

29. La Clede Gas Light Co. v. Mirphy, 170 U. S. 78 (1898); Coverdale v. Edwards, 155 Ind. 374, 58 N. E. 495 (1900); Purnell v. MreLane, 98 ird. 590, 56 Atl. 830 (1904).

30. Rutland Electric Light Co. v. Marble City Electric Light Co., $65 \mathrm{Vt}$. 377, 26 Atl. 635 (1893); Edison Electric Light and Power Co. v. Mierchants Electric Light, Heat and Power Co., 200 Pa. 209, 49 Atl. 766 (1901); People's Electric Light and Power Co. v. Capital Gas and Electric Light Co., $116 \mathrm{Ky}$. 76,75 S. W. 280 (1903).

31. Ess parte Goodrich, 160 Cal. 410, 117 Pac. 451 (1911); Pinney and Boyle Co. v. Los Angeles Gas and Electric Corp., 168 Cal. 12, 141 Pac. 020 (1914). See also Smith, Judicial Interpretation of Public Utility Franchises (1930) 39 YALE L. J. 957. In this respect municipal regulation was supported by the common law rules as to rates and service requirements of common callings. Railway Co. v. Village of Bowling Green, 57 Ohio St. 336, 49 N. E. 121 (1897); Snell v. Clinton Electric Light Co., 196 III. 626, 63 N. E. 1082 (1902); Gainesville $\nabla$. Gainesville Gas and Electric Pover Co., 65 Fla. 404, 62 So. 919 (1913). 
municipality still reserves the right in many jurisdictions to determine when a private plant shall operate within its boundaries..$^{32}$ The development of a large statewide or regional system may, therefore, still be dependent upon the consent of a series of unrelated municipalities. ${ }^{33}$ This stipulation for municipal consent is, however, less inimical to a rational expansion of industry than municipal acquisition of private electric plants as it is authorized in some states. Some years ago the City of Indianapolis resisted the sale of a number of small operating plants to a large corporation which was engaged in consolidating operating territories in Indiana. The Public Service Commission granted a certificate approving the sale on the basis of the economies that would result. In a suit for an injunction brought by the City, the commission's order was upheld, but the court de. clared that under the statutes there remained in the city the authority to purchase that portion of the proposed system which was to operate within the city's boundaries. ${ }^{34}$ In other words, a consolidation of territories, the economies of which had been recognized by the centralized governmental agency, was immediately threatened with disruption by the action of a single political subdivision.

Similar incursions upon private systems have already been made in other states. The City of Puyallup, Washington, several years ago elected to purchase part of the Puget Sound Power and Light System operating within the city's limits. In the condemnation proceedings which followed, much was argued on the amount of severance damages to be allowed the Company for the loss of its Puyallup unit. 35 But there is no indication that the court realized that the very exis-

32. South Shore Utility Co. v. Railroad Commission, 207 Wis. 95, 240 N. W. 784 (1932); De Queen Light and Power Co. v. Curtis, 157 Ark. 288, 248 S. W. 5. (1923); People v. Public Service Commission, 255 N. Y. 232, 174 N. E. 637 (1931). A city has thus been permitted to enjoin the entrance of a singlo wire within its boundaries, Town of Ackley v. Central States Electric Co., 204 Iowa 1246, 214 N. W. 879 (1927), and to make its franchise a condition precedent to the transmission of energy from another city to its own boundaries. State v. Electric Power Co., 116 Kan. 70, 226 Pac. 254 (1924). On the other hand, some courts insist upon the timely assertion of the city's authority as against a plant already established within its boundaries. Stato v. Missouri Utility, 53 S. W. (2d) 394 (Mo. 1932).

33. See N. Y. Times, April 13, 1933, at 25, where the decision of the Yonkers City Council to permit stretching high tension wires along ono of its streets is reported as insuring the completion of interconnection of upstato New York hydro-electric systems with the steam plants of the metropolitan area of New York City. Contra: Parker Young Co. v. State, 83 N. H. 551, 145 Atl. $786^{\circ}$ (1929).

34. Public Service Commission v. City of Indianapolis, 193 Ind. 37, 137 N. E. 705 (1922).

35. Puget Sound Power and Light Co. v. City of Puyallup, 51 F. (2d) 688 (G. C. A. 9th, 1931). 
tence of severance damages is an argument against municipal purchase. A similar procedure has also been followed by municipalities in California. As early as 1916 the City of Los Angeles exercised its authority by appeal to the Railroad Commission to purchase a part of the Southern California Edison system. Here, again, the commission exhaustively treated questions of purchase price and damages caused by severance without noting the retrogressive effect of municipal purchase upon the long run expansion of the industry. ${ }^{36}$ Thus it is that in a similar case in Wisconsin the Railroad Commission could require just compensation to the company from a municipality seeking to acquire the franchise and recognize that "if the city acquires the right to sell directly to the consuming public . . . it has taken something of value from the respondent," 37 but fail to realize that a factor in the loss to the particular company might be the impairment of future light and power facilities in the state as a whole. ${ }^{35}$

Another phase of municipal regulation which may deter an orderly expansion of the industry is the operation of city plants in competition with private systems. Where a municipality merely acquires an existing plant it may be possible by agreement to maintain connections with the main system in the territory so that the economies of consolidation need not be lost. But there would seem to be little justification in the long run for the erection of a municipal plant to compete with a private plant in the same locality. It has been held, however, that a city may in the absence of an express agreement to the contrary resort to such an expensive method of enforcing rate reductions ${ }^{39}$ and that the effect on the existing plant is immaterial, 49

36. Re Los Angeles, P. U. R. 1916F, 593 (Cal. R. C. 1916). See also Ro Los Angeles, P. U. R. 1929C, 389 (Cal. R. C. 1929), involving valuation of municipal acquisition of additional parts of the Southern California Edison System in territory which had been annexed to the City of Los Angeles. See also Re City of Redding, P. U. R. 1919F, 415 (Cal. R. C. 1919); Re City of Oroville, P. U. R. 1922E, 451 (Cal. R. C. 1922).

37. City of Neenah v. Wisconsin Traction, Light, Heat and Power Co., P. U. R. 1915A, 372, 376 (Wis. R. C. 1915).

38. For other instances of municipal acquisition of light and power plants see Re Falls Light and Power Co., P. U. R. 1916D, 151 (Wis. R. C. 1916); Sparta v. Wisconsin-Minnesota Light and Power Co., P. U. R. 1925E, 315 (Wis. R. C. 1925) ; Re Village of Stratford, P. U. R. 1925E, 328 (Wis. R. C. 1925); Re Borough of Reynoldsville, P. U. R. 1918B, 464 (Pa. P. S. C. 1918); San Francisco $\nabla$. Pacific Gas and Electric Co., P. U. R. 1929E, 529 (Cal. R. C. 1929); Blair v. Northern State Power Co., P. U. R. 1931A, 90 (Wis. R. C. 1981).

39. Joplin v. Southwest Missouri Light Co., 191 U. S. 50 (1903). See Note (1931) 41 YALE L. J. 116.

40. People v. Gity of Loveland, 76 Colo. 188, 230 Rac. 399 (1924); Pasadena v. Railroad Commission, 183 Cal. 526, 192 Pac. 25 (1920); Houma Lighting and Ice Co. v. Houma, 127 La. 726, 53 So. 970 (1911). 
although, of course, the municipal plant must not actually "interfere" with the exercise of a valid and subsisting franchise.41 In some jurisdictions the erection of a municipal plant to compete with a private system is made dependent upon approval by the state commission. ${ }^{42}$ But even in such cases, approval is often frankly granted for the mere purpose of keeping rates at a low level. ${ }^{43}$ Once the competition begins, the question becomes almost solely one of rates, raising such issues as the power of the city to require private plants to maintain high rate levels and thus aid the development of the municipal plant, ${ }^{44}$ the right of the company to require the municipal plant to charge no less than cost, ${ }^{45}$ and other points of conflicting interests. ${ }^{46}$ Seldom, however, is the situation solved by a voluntary transfer of the properties of one to the other. ${ }^{47}$

From the beginning, municipal control, whether by franchise to private interests, subsequent recapture, or actual competition, has been maintained primarily to enforce low rates for city inhabitants. It may seriously be questioned whether even the rate problem should be defined in terms of political subdivisions. ${ }^{48}$ But it is certain that the territorial and physical developments of the light and power in-

41. Los Angeles v. Los Angeles Gas and Electric Corp., 251 U. S. 32, 76 (1919); Bell v. David City, 94 Neb. 157, 142 N. W. 523 (1913).

42. Wisconsin Traction, Light, Heat and Power Co. v. Menasha, 157 Wis. 1,145 N. W. 231 (1914).

43. West v. Byron, 153 MId. 464, 138 Atl. 404 (1927).

44. Texas Electric Service Co. v. City of Seymour, 54 F. (2d) 97 (N. D. Tex. 1931) (power denied); Town of Mapleton v. Iowa Public Sorvico Co., 209 Iowa 400,223 N. W. 476 (1929) (power granted).

45. In Re Niagara, Lockport and Ontario Power Co., 229 App. Div. 295, 241 N. Y. Supp. 162 (3d Dep't 1930).

46. It has been held that where a large private system reduces rates in $a$ city to meet municipal competition, it can be required to show causo why similar reduction should not be made throughout its entire territory. Georgin Public Service Commission v. Georgia Power Co., 172 Ga. 71, 157 S. E. 98 (1931). A city may under special statutory language sell power boyond its boundaries, Yamhill Electric Co. v. City of McMinnville, 130 Oro. 300, 274 Pac. 118 (1929). Contra: City of Loveland v. Public Utilities Commission, 87 Colo. 556, 289 Pac. 1090 (1930).

47. Re Niagara Lockport and Ontario Power Co., P. U. R. 1932A, 92 (N. Y. P. S. C. 1932). For statistics on the flux of ownership see Doran, Crinana Character aNd EXTENT OF MUNICIPAL OWNERSHIP IN THE ELECTRIO LIaHT AND POWER INDUSTRY (1929).

48. Cf. Wabash Valley Electric Co. v. Young, 53 Sup. Ct. 234 (1033), where valuation of city property of a system apart from that of the ontire system for rate making purposes was sustained. Such a decision frils to recognize (a) that city boundaries have as a matter of fact been transcended by industrial developments and (b) that consumers in densely populated areas should share the cost of maintaining service in sparsely settled districts. See Note (1932) 41 Y ALE L. J. 912. 
dustry are no longer determined in fact by the boundaries of cities, towns and villages. Where private companies have extended beyond those boundaries, their systems should not be harassed by a continuation of archaic municipal regulations. It should be noted, however, that criticism of municipal interference with territorial expansion implies neither that private systems have been properly extended, nor that ultimate public operation is unsound. Such criticism does imply, however, that in extending their systems beyond city limits private companies have responded to the natural growth of the industry and that public operation is entitled to be considered only when it makes a similar response.

The influence of municipal regulation upon the territorial expansion of the industry has, therefore, been entirely negative. It remains to be considered whether the centralized agencies of state governments in which an increasing amount of control has been reposed have been able to exercise any degree of positive influence on this phase of the industry's development. The most direct authority exercised by these state agencies for the control of expansion in the light and power industry is to be found in the administration of certificates of public necessity and convenience. In a majority of states it is now provided that no private utility shall enter new territory, make new plant additions or otherwise enlarge, alter or diminish its enterprise without having first obtained a certificate of approval from the appointed regulatory agency of the state. ${ }^{10}$ As in the case of municipal control, however, this function of state commissions has been justified as a means for controlling rates and service.

49. All states require such certificates for territorial extensions of electric utilities except Connecticut, Georgia, Iowa, Kentucky, Louisiana, Massachusetts, Minnesota, Mrississippi, Miontana, New Miexico, Ohio, South Carolina, South Dakota, Texas, Washington and Wyoming. West Virginia requires certification only of water power developments.

It is beyond the scope of this article to consider in detail the rules governing the granting of certificates. The purpose here is merely to appraise the administration of this phase of commission authority in its effect upon a rationalization of the light and power industry. For general discussions see Hall, Certificates of Public Necessity and Convenionce (1929-1930) 28 IIrcH. L. REv. 107, 276; Miosher aNd Crawford, PUBLIC UTILITY REgulation (1933) c. 8.

50. Said the Supreme Court of Idaho, upholding the constitutionality of certification: "It is too late to question the power of the legislature to regulate public utilities respecting rates, service, etc. That power presupposes intelligent regulation and necessarily carries with it the power to employ the means necessary and proper for such intelligent regulation." Idaho Light and Power Co. v. Bloomquist, 26 Idaho 222, 254, 141 Pac. 1083, 1093 (1914). The court in that case found that the elimination of destructive competition was a necessary means for rate regulation. See also Pirie v. Commission, 72 Colo. 67, 209 Pac. 640 (1922); State v. Atkinson, 275 Mo. 325, 204 S. W. 
furtherance of this policy courts have refused in most cases to interfere with the judgment of the commission in granting or withholding a particular certificate. This has been true, even though the commission disagrees with the municipality on the reasonableness of the rates of the existing utility, ${ }^{61}$ or grants a certificate to a new company on the ground that the existing utility is giving inadequate service. 52

But in the exercise of this authority commissions have failed to indicate a uniform policy. Immediate considerations have often been as influential as programs for future developments. Thus, a commission on one occasion may be sustained in dividing the territory of a single borough between two companies, diction there may be approval of the activities of consolidation on the part of a large. system seeking autonomous operation in an increasing territory, even though other smaller companies are left by the wayside. ${ }^{54}$ One commission has been reversed for granting to the small subsidiary of a coal company a certificate enabling it to tap the territory held by a large system; ${ }^{55}$ while another commission has successfully restrained the erection of a six mile extension of the transmission line of one of the largest systems in the jurisdiction.

In spite of this lack of uniformity, however, some commissions have consistently looked with favor upon territorial expansion, but their attitude has been expressed rather through approval of privately initiated consolidations and extensions than by their own affirmative acts. At an early date consolidations effected by private companies

897 (1918); Oneonta Light and Power Co. v. Commission, 180 App. Div, 32, 167 N. Y. Supp. 486 (3d Dep't 1917).

51. Jenkins Township v. Commission, 65 Pa. Sup. Ct. 122 (1916); Relief Electric Light Company's Petition, 63 Pa. Sup. Ct. 1 (1916).

52. Fogelsville Electric Co. v. Pennsylvania Power and Light Co., $271 \mathrm{~Pa}$. 237, 114 Atl. 822 (1921).

53. Eastern New Jersey Power Co. v. Board of Public Utilities Commissioners, 6 N. J. Misc. 118, 140 Atl. 258 (Sup. Ct. 1928).

54. Coverdale Electric Light Co. v. Public Service Commission, 68 Pa. Sup. Ct. 351 (1917). See also Harmony Electric Co. v. Commission, 80 Pa. Sup. Ct. 46 (1922), where one system was authorized to extend its sorvice to tho generation of energy :by steam as well as by water in the interests of consolidation. In that case the "court "was ready to sustain the commission's endorsement of voluntary consolidation by a large number of companies because the mergers had begun prior to the effective date of the Public Service Commission Act. See :Harmony ' Electric Co. v. Commission, 275 Pa. 242, 119 Atl. 712 (1923).

55. Mllinois Power and Light Corp." v. Commerce Commission, 320 IIl. 427, 151'N. E. :236 (1926).

56. Public 'Service Commission v., Kansas City Power and Light Co, 325 Mo. 1217, 31 S.:W. (2d) 167 (1930). See also Kansas Gas and Electric Co. v. Public'Service .Commission, 124 Kan. 690, 261. Pac. 592 (1927). 
within particular municipalities were recognized as a move in the right direction..$^{57}$ Indeed, there are instances in which courts and commissions have looked upon territorial development under private auspices as the proper method of expansion."s As recently as 1929 the New Hampshire Commission declared that "Utilities should not be deprived from doing as they see fit with their properties, provided their acts are not illegal or harmful to the public." 5 Similarly, the Supreme Court of Pennsylvania, in approving the merger of a light and power distributing company with a hydroelectric generating company, gave as its reason the prevention of economic waste and the possibility of more efficient service at reduced rates, concluding that "These considerations make the consolidation or merger of these plants a matter of public policy, which should be accelerated by a liberal construction of the acts empowering merger or purchase." $c 0$

But where two or more private systems are competing for certificates to permit extensions into the same territory, a commission is often compelled to abandon this passive attitude. In 1930 the River Falls Power Company petitioned the Alabama Commission for authority to construct and operate a transmission line in furtherance of its program to develop interconnections among the various operating units of its system. The Alabama Power Company intervened to urge that the petition be denied in view of the fact that it already had under construction a transmission line which could serve the territory more economically than the petitioner's line. The commission, although persuaded by the facts presented through the intervention, found that it was without authority to order the petitioner's operating units to purchase power from the Alabama Power line. It therefore granted the petition but stipulated that the rates charged in the territory should be as low as would have been possible if energy had been purchased from the intervener. The commission also pointed to the necessity for additional authority to accomplish by direct order the control over territorial development which it was forced to attempt to exert by indirection..$^{01}$ Other commissions faced

57. Idaho Light and Power Co. v. Bloomquist, supre note 50; Saginaw Power Co. v. City of Saginaw, 193 Fed. 1008 (E. D. Mich. 1911).

58. Weld v. Board of Commissioners, 197 Miass. 556, 84 N. E. 101 (1908).

59. Re Franklin Light and Power Co., P. U. R. 1929D, 678, 679 (N. H. P. S. C. 1929). Accord: Re Ashland Electric Light and Power Co., P. U. R. 1929B, 326 (Me. P. S. C. 1929).

60. York Haven Co. v. Commission, 287 Pa. 241, 245, 134 Atl. 419, 420 (1926).

61. Re River Falls Power Co., P. U. R. 1930E, 97, 103 (Ala. P. S. C. 1931). "It is the view of the Commission that the legislature of Alabama should clothe the Commission with definite and certain authority to deal with all public utilities rendering the same or similar service to the people of Alabama, 
with similar controversies have exhibited varying degrees of attention to the broader issues. Thus, as between two petitions for certificates to construct hydrodams, one by a large private power system, the other by the subsidiary of an electro-chemical industry, the Tennessee Commission has favored the latter on the ground that it would bring a new industry into the territory. ${ }^{\circ 2}$ Normally, however, when faced with petitions from two utilities, a commission will consider "whether or not the extension to the new territory to be served logically and geographically falls in the territory of one company or the other." od Hence, while a pre-existing franchise in another company has been held to be no bar to the entry of a large system, whose program called for the development of a wide area of supply, ${ }^{64}$ it has also been stated as the basis for a decision on competing petitions, "It is the opinion of the Commission that one utility should not attempt to pierce an open space that may exist in the territory surrounded by another utility, but that the utility should keep before it the fact that wherever it is possible to block out territory with the view of eventually serving the territory with a system approaching a network effect, will be [sic] more in the interest of the public than to build an extension into a territory which opens but very little opportunity to build it into a network system that can be supplied from more than one source." 65

Despite, however, these instances of competition among private systems for new territory, it is to be expected that the problem of control in the future will be that raised by the voluntary coordination of private systems as indicated by the recently completed intercon-

so as to provide the state as a whole with service of the best and most economical nature. To make it plain, it is our view that the Commission should have the clear authority to require utilities to buy, sell, and exchange their commodities and service so that the state can prevent burdening the peoplo with unnecessary capital investment in the duplication of lines and systems, and with the unnecessary duplication of overhead operating costs which enter into these operations."

62. Re Tennessee Eastern Power Co., P. U. R. 1929E, 175 (Tenn. R. \& P. U. C. 1929). Cf. Re Fox \& Putnam v. Parker Young Co., P. U. R. 1920D, 403 (N. H. P. S. C. 1929), where preference was given to an electric utility as against a manufacturing company.

63. Re Ozark Utilities Co., P. U. R. 1929D, 592, 599 (Mo. P. S. C. 1029).

64. Re Central Maine Power Co., P. U. R. 1932C, 157 (Me. P. U. C. 1932).

65. Re Kansas City Power and Light Co., P. U. R. 1931A, 463, 466 (Mo. P. S. C. 1931). So also it has been held that the transfer of transmission lines to a large private system rather than to a municipal generating system from which the transmission company had been purchasing its enorgy would insure a more economical development of the territory. Ottawa v. Public Service Commission, 130 Kan. 867, 288 Pac. 556 (1930). 
nections in the northeastern states. ${ }^{\circ}$ A phase of this particular scheme came before the Public Service Commission of New York in 1932, under a petition by the New York Light and Power Company for certification of a main transmission line from the northern boundary of Westchester County to Albany County. ${ }^{67}$ The purpose of the line, as stated in the petition and established at the hearings, was to connect the steam generation system of the metropolitan area of New York City with the hydroelectric sources of the Niagara Hudson upstate system. After close scrutiny of the financial aspects of the proposition, the commission stated that the tranmission line "seems to be in the public interest, in that it will reduce the cost of generating and distributing electric energy to the consumers of the New York Power and Light Corporation and of the electric companies in Greater New York and Westchester County. . . " os It was also recognized that the line was to form an integral part of an interstate scheme, and that ultimately it might interfere with the utilization of St. Lawrence power under a program to be developed by the Power Authority of the State of New York. The commission did not presume to pass upon the soundness of the entire interstate scheme, but it did grant a certificate subject in part to future action of the New York Power Authority.

Such cases as the New York Commission's order on the petition of the New York Power and Light corporation ${ }^{69}$ and the Alabama Commission's decision in Re River Falls Power Company ${ }^{70}$ represent, however, exceptions to the typical attitude in granting a certificate. Even in those cases there continues to be an implied reliance upon the initiative of private management to make proposals for consolidation. But in the normal case, the proposals themselves are seldom scrutinized. ${ }^{11}$ This is especially true where the question concerns merely a corporate consolidation or merger. ${ }^{72}$ It is also to be

66. Note 20 , supra.

67. Re New York Power and Light Corp., P. U. R. 1932A, 357 (N. Y. P. S. C. 1932).

68. Id. at 366 .

69. Note 67, supra.

70. Note 61, supra.

71. See $R e$ St. Louis Public Service Co., P. U. R. 1932C, 161 (AIo. P. S. C. 1932). Some commissions still conceive their function to be merely to ascertain the true cost of the extensions. [Re Wisconsin Power and Lirght Co., P. U. R. 1931C, 289 (Wis. R. C. 1931) ; $R e$ Niagara Hudson Power Corp., P. U. R. 1932C, 486 (N. Y. P. S. C. 1932)]; while others are solely concerned with the immediate effect upon rates. Ro Chester Valley Electric Co., P. U. R. 1932A, 227 (Pa. P. S. C. 1932).

72. Re Maryland Light and Power Co., P. U. R. 1930B, 465 (MId. P. S. C. 1930); $R e$ Fall Mountain Electric Co., P. U. R. 1932C, 275 (N. H. P. S. C. 
noted that in a considerable number of states no control at all is exerted. ${ }^{73}$ Nor is it definitely settled that all branches of the light and power industry are subject to the jurisdiction of state commissions. In the absence of federal legislation no certain authority exists to control the incidents of interstate transmission, ${ }^{74}$ while, on the other hand, the tendency in a number of states to restrict the exportation of power has a definitely retarding effect upon a rational expansion of the industry. ${ }^{75}$ Furthermore, jurisdiction of state commissions depends upon statutory definitions of companies engaged in the light and power business and there is a diversity of opinion as to whether generation and transmission units are "public utilities" along with those companies which distribute energy to consumers.70

It is, therefore, evident that under existing methods of regulation there is little opportunity for governmental direction in the develop. ment of the light and power industry. While much authority has already been transferred from municipalities to centralized agencies of the state, political subdivisions continue to exert a retarding effect upon industrial growth through their power to exclude, acquire or compete with private systems. On the other hand, the state agencies have been sátisfied to let private industry initiate programs of expansion, and their administration of restraints upon such programs

1932). See Hall, State Control of Consolidation of Public Utilitios (1932) U. OF PA. L. REv. 8.

73. Note 49 , supra.

74. Public Utilities Commission v. Attleboro Steam and Electric Co., 273 U. S. 83 (1927). Cf. Western Distributing Co. v. Kansas Public Servico Commission, 285 U. S. 119 (1932).

75. Elsbree, Interstate Transmission of Electric Power (1931) c. 2; Simonton, Power of a State to Control Export of Hudro-Electrio Energy (1982) 39 W. VA. L. Q. 4.

76. The Maine Commission has held that it has no jurisdiction over tho sale of the properties of a generation company. Re International Power Co., P. U. R. 1931E, 65 (Me. P. U. C. 1931). See also State v. Power Transmission Co., 320 Mo. 1146, 9 S.'W. (2d) 589 (1928); Chippewa Power Co. v. Rnillond Commission, 188 Wis. 246, 205 N. W. 900 (1925); Benjamin v. Great Northorn Utilities Co., P. U. R. 1924B, 705 (Mont. P. S. C. 1924) ; Public Service Commission v. Montana Water and Power Co., P. U. R. 1926A, 689 (Mont. P. S. C. 1926). On the other hand, it has been held that for various purposes such companies are subject to commission control. Salisbury Railway Co. v. Southern Power Co., 179 N. C. 18, 101 S. E. 593 (1919); Southern Oklahoma Power Co. v. Corporation Commission, 96 Okla. 53, 220 Pac. 370 (1923); Ro East St. Louis Light and Power Co., P. U. R. 1919E, 379 (Ill. P. U. C. 1919). Intercorporate: affiliations, have often been considered the determinant. Ro West Missouri, Power Ga., P. U. R.'1929A, 61 (Mo. P. S. C. 1929); Ohio Mining Co. v. Public Utilities Commission, 106 Ohio St. 138, 140 N. E. 143 (1922). Cf. : Southern Ohio :Power Co.'v. 'Public Utilities Commission, 110 Ohio St. 246,143 N. E. $700 \cdot(1924)$. 
has been neither farsighted nor uniform. There are, furthermore, strong indications that just as the industry at an early date outgrew the boundaries of municipalities, it may now be transcending state lines. There is a fundamental fallacy in the assumption that any industry can be made to fit the procrustean frameworks of politically divided territories.

What, then, becomes of the problem of government in this field? Not the abdication of public responsibility, nor the reliance merely upon punitive regulation. On this point the plight of the railroads is convincing. Private management alone is incompetent to rationalize industrial expansion. But on the other hand, drastic preemption of the entire field by governmental ownership would likewise fail at this time to solve the problem. Revolutions in any degree involve economic loss that is justified only by the ultimate balance of benefits. We have gone too far in permitting private development of the light and power industry to resort at once to nationalizing processes. The middle road still remains the wisest course.

The program of The New York Power Authority seems to recognize the possibilities of such a course. Delegated by the state to supervise along with the national government the development of the St. Lawrence River as a waterway from the Atlantic to the Great Lakes, it is also empowered to create out of such development huge sources of hydro-electric power. ${ }^{77}$ While much attention must be given the cost of engineering and other financial aspects of the power project, the Power Authority has already recognized that fruition of the project must ultimately depend upon transmission and distribution. To that end negotiations are to be carried on with private systems. ${ }^{78}$ Such a program necessarily implies an increase in governmental initiative in promoting a proper expansion of the industry.

The prospectus of the New York Power Authority may well lead the way to a coordination of private and public agencies throughout the country. Particularly, it should influence the development of federal agencies. Thus far, for instance, the Federal Power Commission ${ }^{79}$ has been interested chiefly in the conservation of power sources on the public domain and in the cost of proposed private developments, with the end of recapture in view. 80 It has awaited the applications of private systems for power sites instead of utilizing this public facility as a means for promoting orderly expansion of

77. Power Authority of New York, Second Annual Report (1933) 9.

78. $I d$. at 50.

79. 41 StAT. 1063 (1920), 16 U. S. C. $\$ 793$ ct seq. (1926); 46 Star. 797 (1930), 16 U. S. C. SuPP. VI \& 792 et scq. (1932).

80. Re Alabama Power Co., P. U. R. 1932D, 345 (Fed. P. C. 1932). See Comments (1932) 42 YALE L. J. 66, 248. 
the industry. In this respect the passive policy of the Power Commission has not been egregious. It is merely one more indication of the abdication of governmental agencies from any part in the development of this rapidly expanding industry. ${ }^{81}$

81. A study necessarily to follow the instant analysis is a consideration of the means by which under our dual system of government rationalization can be effected. On this question, see the prophetic exposition of Interstate Compacts by Frankfurter and Landis, The Compact Clause of tho Constitution (1925) 34 YALE L. J. 685.

Another corollary to be presented is the example of the reorganization of the light and power industry in Great Britain now in process under governmental auspices. See Reports 1-12, Electricity Commissioners, Great Britain; Reports 1-5, Central Electricity Board, Great Britain. 